\title{
Commentary \\ Recent advances in technologies for the detection of occult metastatic cells in bone marrow of breast cancer patients
}

Stephan Braun and Nadia Harbeck

Department of Obstetrics and Gynecology, Clinical Research Unit, Technical University, Munich, Germany

Correspondence: Stephan Braun, MD, Department of Obstetrics and Gynecology, Clinical Research Unit, Technical University, Ismaninger Strasse 22, D-81675 München, Germany. Tel: +49 894140 7476; fax: +49 894140 7410; e-mail: stephan.braun@|rz.tum.de

Received: 24 April 2001

Accepted: 4 June 2001

Published: 28 June 2001

Breast Cancer Res 2001, 3:285-288

(C) 2001 BioMed Central Ltd

(Print ISSN 1465-5411; Online ISSN 1465-542X)

\begin{abstract}
Approximately half of breast cancer patients with stage I-III disease will suffer metastatic disease despite resection with tumour-free margins. In 30-40\% of these patients, individual carcinoma cells can already be detected at the time of primary therapy in cytological bone marrow preparations using immunocytochemistry. Numerous prospective clinical studies have shown that the presence of occult metastatic cells in bone marrow is prognostically relevant to patient survival. Only a few studies failed to do so, thus stimulating a critical discussion on the methodology and clinical value of bone marrow analysis. The potential for obtaining improved prognostic information on patient outcome, for monitoring tumour cell eradication during adjuvant and palliative systemic therapy, and for specifically targeting tumour biological therapies are intriguing clinical opportunities that may be afforded by bone marrow analysis. Standardized and robust methodology is a prerequisite for clinical application of these techniques, however.
\end{abstract}

Keywords: breast cancer, immunocytochemistry, micrometastasis, polymerase chain reaction (PCR), prognosis

\section{Introduction}

The search for occult metastatic cells in patients with small breast tumours, which have been resected with tumour-free margins, has attracted great interest during the past decade. Early tumour cell dissemination is now recognized as a cause of metastatic disease [1-3], which is the leading cause of death from cancer in the Western industrialized world. The immunocytochemical search for such disseminated tumour cells in bone marrow was first investigated in breast cancer [4]. It is thus perhaps somewhat ironic that the clinical significance of metastatic breast cancer cells has remained controversial. The discrepant results of clinical follow-up studies are best explained by substantial methodological variations, study populations of insufficient size, and short periods of clinical follow up. Thus, the clinical applications for bone marrow analysis in patients with solid tumours are still controversially discussed $[5,6]$.

Regarding methodological heterogeneity, a similar situation occurred in detection and evaluation of minimal residual disease in lymphoma, which, in an international effort, was successfully overcome some 10 years ago [7]. In patients with lymphoma standardized detection procedures now contribute to a refined staging system, resulting in individualized treatment options and an improved outcome for such patients [8]. This example clearly highlights the efforts that are now necessary in order to implement screening for occult metastatic carcinoma cells into current risk classification systems and treatment protocols for patients with breast cancer and other solid tumours. The present commentary focuses on recent advances in

$\mathrm{PCR}=$ polymerase chain reaction. 
Table 1

\begin{tabular}{|c|c|c|c|c|c|}
\hline Marker & Preparation & Patients $(n)$ & Detection rate (\%) & Prognostic value & Reference \\
\hline Mucin & Biopsy & 159 & 16 & None & [15] \\
\hline Mucin & Cell smears & 25 & 48 & None & [14] \\
\hline Mucin/CK & Cell smears & 71 & 38 & None & [13] \\
\hline Mucin/CK & Cell smears & 49 & 37 & DFS, OS & [11] \\
\hline Mucin/CK & Cell smears & 100 & 38 & DFS, OS* & [10] \\
\hline Mucin & Cell smears & 727 & 43 & DFS, OS* & [3] \\
\hline CK & Biopsy & 128 & 19 & DFS, OS* & [9] \\
\hline CK18 & Cytospins & 581 & 28 & None & [12] \\
\hline Mucin & Cell smears & 350 & 25 & DFS, OS & [2] \\
\hline CK & Cytospins & 552 & 36 & DDFS, OS* & [1] \\
\hline
\end{tabular}

*Prognostic value confirmed by multivariate analysis. CK, cytokeratin; DDFS, distant disease-free survival; DFS, disease-free survival; OS, overall survival.

technologies for the detection of occult metastatic cells in bone marrow in breast cancer patients.

\section{Methods of tumour cell detection}

Immunocytochemical and molecular approaches are currently being evaluated for their reliability and clinical utility in detecting isolated metastatic cells in bone marrow of breast cancer patients.

\section{Immunocytochemistry}

Data on bone marrow screening for breast cancer micrometastasis have thus far been almost exclusively based on immunocytochemical analyses. Although numerous studies reported a strong association of the assay used with prognosis [1-3,9-11], other investigators found no such association of bone marrow micrometastases with patient outcome [12-15], as summarized in Table 1. Part of the reason for the discrepant results of clinical follow-up studies is substantial methodological variation, resulting in a wide range of detection rates (4-48\%) within comparable study populations [16].

The extreme diversity of antibodies used for identification of epithelial cells (Table 1) is the major confounding variable, and renders the results of most of the cited studies almost incomparable. Because the specificity of the immunocytochemical assay for detection of single tumour cells is one of the key methodogical issues, noncarcinoma control patients were included and evaluated continuously in our studies [1,17], whereas most other groups did not report such data. This issue is of particular importance in the case of polymorphic epithelial mucins, such as epithelial membrane antigen or mucin, which are also expressed by haematopoietic precursor cells such as erythroblasts [18-20]. In contrast, using validated antibodies directed against cytokeratins as major constituents of epithelial cells, no such cross-reactivity was observed. Although illegitimate cytokeratin mRNA expression by haematopoietic cells might be detected by sensitive polymerase chain reaction (PCR) technologies, this problem is not relevant to immunocytochemical approaches because cytokeratins are very rarely detected in mesenchymal cells $[1,18]$. Thus, the rare $(<1 \%)$ occurrence of cytokeratin-positive aspirates in noncarcinoma control patients [1] may reflect pathological conditions, including chronic inflammations, or may indicate spurious staining of aberrant plasmacytoid cells and the presence of an as yet undiagnosed malignancy.

Additional justification for using cytokeratin-specific antibodies in screening assays for occult breast carcinoma cells can be derived from two recent studies. Multiple chromosomal aberrations were detected in cytokeratinpositive bone marrow micrometastases by interphase fluorescent in situ hybridization analysis [21] and comparative genome hybridization of genomic DNA [22], thus demonstrating that these occult metastatic cells are indeed tumour cells.

Even if anticytokeratin monoclonal antibodies on cytospin preparations are used, however, the detection rate is still affected by blood contamination of the bone marrow specimen, the number of aspirates analyzed, and the number of mononucleated bone marrow cells screened per aspiration site [18]. Thus, the results of any immunocytochemical screening test for isolated carcinoma cells in bone marrow largely depend on methodological issues. This emphasizes the urgent need for an internationally standardized protocol as a prerequisite for implementation of such screening into clinical practice. Taking recent methodological and clinical studies into account, a stan- 
dardized assay may consist of a specificity proven monoclonal antibody (ie A45-B/B3) and sufficient sample size (ie $2 \times 10^{6}$ mononucleated cells) obtained from two aspiration sites $[1,18]$. The use of automated screening devices allows rapid and reproducible evaluation of the immunocytochemical assay [23]. By using such a standardized immunocytochemical detection assay, phenotyping of single tumour cells by multiple staining procedures allows further characterization of the actual target cells for specific tumour biological therapies.

\section{Polymerase chain reaction}

Although increased sensitivity of the reverse transcription (RT)-PCR technology as compared with immuncytochemistry is conceivable, the majority of studies conducted thus far lack valid comparison with a true immunocytochemical benchmark method, as mentioned above. In addition, as a limiting factor in the detection of micrometastatic cells by RT-PCR, illegitimate transcription of tumour-associated or epithelia-specific genes was reported for haematopoietic cells [24]. Because of the extreme genetic instability of breast carcinoma cells, deficient expression of the marker gene in micrometastatic tumour cells may lower the actual sensitivity as compared with immunocytochemistry. In addition, no distinction between viable and nonviable tumour cells and no clear quantification of the tumour cell load (low level versus high level mRNA/DNA expressors) can be achieved. With quantitative RT-PCR techniques that enable an estimate of the number of reference gene transcripts in bone marrow cells in relation to the marker gene transcripts (eg cytokeratin), a cutoff level can be created to distinguish between malignant and nonmalignant cells [25]. Prospective clinical studies that show methodological validity and clinical relevance of these new techniques in comparison with a standard immunocytochemical assay are, however, needed before PCR-based techniques can be considered for clinical application.

\section{Conclusion}

The current strategies for detection of occult metastatic cells in bone marrow of breast cancer patients provide intriguing clinical opportunities for improved tumour staging, therapeutic targeting and, for the first time, the possibility to monitor the efficacy of adjuvant systemic therapy $[26,27]$. At present we feel that there is a need for concerted international activity to implement standardized immunocytochemical procedures that are already available, which may then serve as a 'gold standard' with which to compare novel diagnostic approaches. The development of new PCR-based methods may increase assay sensitivity and help to reduce the influence of varying levels of expertise among observers, but these methods still require validation in clinical follow-up studies. In order to obtain a higher level of evidence [28] regarding the prognostic and predictive impact of occult metastatic cells in the bone marrow of breast cancer patients, further clinical studies that apply the available methodological improvements are urgently needed.

\section{References}

1. Braun S, Pantel K, Müller P, Janni W, Hepp F, Kentenich CRM, Gastroph S, Wischnik A, Dimpfl T, Kindermann G, Riethmüller G, Schlimok G: Cytokeratin-positive cells in the bone marrow and survival of patients with stage I, II or III breast cancer. N Engl J Med 2000, 342:525-533.

2. Mansi JL, Gogas H, Bliss JM, Gazet JC, Berger U, Coombes RC: Outcome of primary-breast-cancer patients with micrometastases: a long-term follow-up. Lancet 1999, 354:197-202.

3. Diel IJ, Kaufmann M, Costa SD, Holle R, von Minckwitz G, Solomayerr EF, Kaul S, Bastert G: Micrometastatic breast cancer cells in bone marrow at primary surgery: prognostic value in comparison with nodal status. J Natl Cancer Inst 1996, 88:1652-1664.

4. Dearnaley D, Sloane J, Ormerod M, Steele K, Coombes R, Clink $\mathrm{H}$, Powles T, Ford H, Gazet J-C, Neville A: Increased detection of mammary carcinoma cells in marrow smears using antisera to epithelial membrane antigen. Br J Cancer 1983, 44:8590.

5. Funke I, Schraut W: Meta-analysis of studies on bone marrow micrometastases: an independent prognostic impact remains to be substantiated. J Clin Oncol 1998, 16:557-566.

6. Pantel K, Cote RJ, Fodstad Ø: Detection and clinical importance of micrometastic disease. J Natl Cancer Inst 1999, 91: 1113-1124.

7. Pongers-Willemse MJ, Seriu T, Stolz F, d'Aniello E, Gameiro P Pisa P, Gonzalez M, Bartram CR, Panzer-Grumayer ER, Biondi A, San Miguel JF, van Dongen JJ: Primers and protocols for standardized detection of minimal residual disease in acute lymphoblastic leukemia using immunoglobulin and $T$ cell receptor gene rearrangements and TAL1 deletions as PCR targets: report of the BIOMED-1 concerted action: investigation of minimal residual disease in acute leukemia. Leukemia 1999, 13:110-118.

8. Biondi A, Valsecchi MG, Seriu T, D'Aniello E, Willemse MJ, Fasching K, Pannunzio A, Gadner H, Schrappe M, Kamps WA, Bartram CR, van Dongen JJ, Panzer-Grumayer ER: Molecular detection of minimal residual disease is a strong predictive factor of relapse in childhood B-lineage acute lymphoblastic leukemia with medium risk features. A case control study of the International BFM study group. Leukemia 2000, 14:19391943.

9. Landys K, Persson S, Kovarik J, Hultborn R, Holmberg E: Prognostic value of bone marrow biopsy in operable breast cancer patients at the time of initial diagnosis: results of a 20-year median follow-up. Breast Cancer Res Treat 1998, 49:27-33.

10. Harbeck N, Untch M, Pache L, Eiermann W: Tumour cell detection in the bone marrow of breast cancer patients at primary therapy: results of a 3-year median follow-up. $\mathrm{Br} J$ Cancer 1994, 69:566-571.

11. Cote RJ, Rosen PP, Lesser ML, Old LJ, Osborne MP: Prediction of early relapse in patients with operable breast cancer by detection of occult bone marrow micrometastases. J Clin Oncol 1991, 9:1749-1756.

12. Untch M, Kahlert S, Funke I, Boettcher B, Konecny G, NestleKraemling $C$, Bauerfeind I: Detection of cytokeratin 18-positive cells in bone marrow of breast cancer patients: no prediction of bad outcome [abstract]. Proc ASCO 1999, 18:639a (abstract 2472).

13. Singletary SE, Larry L, Trucker SL, Spitzer G: Detection of micrometastatic tumor cells in bone marrow of breast carcinoma patients. J Surg Oncol 1991, 47:32-36.

14. Kirk SJ, Cooper GG, Hoper M, Watt PC, Roy AD, Olding-Smee $\mathrm{W}$ : The prognostic significance of marrow micrometastases in women with early breast cancer. Eur J Surg Oncol 1990, 16: 481-485.

15. Porro G, Menard S, Tagliabue E, Orefice S, Salvadori B, Squicciarini $\mathrm{P}$, Andreola S, Rilke F, Colnaghi Ml: Monoclonal antibody detection of carcinoma cells in bone marrow biopsy specimens from breast cancer patients. Cancer 1988, 61:2407-2411.

16. Osborne $M$, Rosen $P$ : Detection and management of bone marrow micrometastases in breast cancer. Oncology 1994, 8: 25-36. 
17. Braun S, Hepp F, Janni W, Blankenstein T, Schindlbeck C, Riethmüller G, Pantel K: Occult tumor cells in bone marrow of patients with locoregionally restricted ovarian cancer predict early distant metastatic relapse. J Clin Oncol 2001, 19: 368-375.

18. Pantel K, Schlimok G, Angstwurm M, Weckermann C, Schmaus W, Gath H, Passlick B, Izbicki J, Riethmüller G: Methodological analysis of immunocytochemical screening for disseminated epithelial tumor cells in bone marrow. J Hematother 1994, 3: 165-173.

19. Braun S, Müller M, Hepp F, Schlimok G, Riethmüller G, Pantel K: Re: Micrometastatic breast cancer cells in bone marrow at primary surgery: prognostic value in comparison with nodal status. J Nat/ Cancer Inst 1998, 90:1099-1100.

20. Brugger W, Bühring HJ, Grünebach F, Vogel W, Kaul S, Müller R, Brümmendorf TH, Ziegler BL, Rappold I, Brossart P, Scheding S, Kanz L: Expression of MUC-1 epitopes on normal bone marrow: Implications for the detection of micrometastatic tumor cells. J Clin Oncol 1999, 17:1535-1544.

21. Müller $P$, Carroll $P$, Bowers $E$, Moore II $D$, Cher M, Presti J, Wessman M, Pallavicini MG: Low frequency epithelial cells in bone marrow from prostate carcinoma patients are cytogenetically aberrant. Cancer 1998, 83:538-546.

22. Klein CA, Schmidt-Kittler O, Schardt JA, Pantel K, Speicher MR, Riethmüller G: Comparative genomic hybridization, loss of heterozygosity, and DNA sequence analysis of single cells. Proc Natl Acad Sci USA 1999, 96:4494-4499.

23. Bauer KD, de la Torre-Bueno J, Diel IJ, Hawes D, Decker WJ, Priddy C, Bossy B, Ludmann S, Yamamoto K, Masih AS, Espinoza FP, Harrington DS: Reliable and sensitive analysis of occult bone marrow metastases using automated cellular imaging. Clin Cancer Res 2000, 6:3552-3559.

24. Zippelius A, Kufer P, Honold G, Köllermann MW, Oberneder R, Schlimok G, Riethmüller G, Pantel K: Limitations of reverse transcriptase-polymerase chain reaction for detection of micrometastatic epithelial cancer cells in bone marrow. J Clin Oncol 1997, 15:2701-2708.

25. Slade MJ, Smith BM, Sinnett HD, Cross NCP, Coombes RC: Quantitative polymerase chain reaction for the detection of micrometastases in patients with breast cancer. $J$ Clin Oncol 1999, 17:870-879.

26. Braun S, Kentenich CRM, Janni W, Hepp F, de Waal J, Willgeroth F, Sommer HL: Lack of effect of adjuvant chemotherapy no the elimination of single dormant tumor cells in bone marrow of high-risk breast cancer patients. J Clin Oncol 2000, 18:80-86.

27. Braun S, Hepp F, Kentenich CRM, Janni W, Pantel K, Riethmüller $\mathrm{G}$, Sommer HL: Monoclonal antibody therapy with edrecolomab in breast cancer patients: monitoring of elimination of disseminated cytokeratin-positive tumor cells in bone marrow. Clin Cancer Res 1999, 5:3999-4004.

28. Hayes DF, Bast RC, Desch CE, Fritsche H, Kemeny NE, Jessup JM, Locker GY, Macdonald JS, Mennel RG, Norton L, Ravdin P, Taube S, Winn RJ: Tumor marker utility grading system: a framework to evaluate clinical utility of tumor markers. $J$ Natl Cancer Inst 1996, 88:1456-1466. 